\title{
Impact of Mining Industry on Environmental Fabric -A Case Study of Rajasthan State in India
}

\author{
S.K. Maanju, K. Saha, \\ Vikram University, Ujjain (M.P.) \\ Government Dungar College, Bikaner(Raj.)
}

\begin{abstract}
Rajasthan is one of the main mineral potential State of India and during last 30 years it has witnessed enormously expansion of mining industries but mining of most of the minor minerals coupled with changing climate has posed serious problems to the environmental fabric in the State, apart from base metal beneficiation plants. Groundwater is also being polluted day by day by effluents generated from mineral wastes and beneficiation processes in the vicinity of mining sites such as: Khetri \& Zawar etc.

Mining industry has deteriorated quality of groundwater resources in the State of Rajasthan and these industries are becoming centers of pollution sources which need timely actions at government level so that natural resources such as groundwater can be protected.
\end{abstract}

Key words: Environment, Groundwater, Mining, Protection, Pollution.

\section{Introduction}

Environmental is a complex aggregate of external conditions which affect the life, development and survival of all organisms. It is composed of biophysical and socio-economic elements. Environment and people have a reciprocal relationship. Man has been exploiting natural resources for making his life more comfortable. The natural resources are part of eco-system wherein a mutually balanced relationship exists between living creatures and natural forces. Any exploitation of natural resources means changes within the eco-system and which spreads its influence to all organism. Mining and related activities have a profound and wide influence on the earth's natural environment. Mining industries enhance comfort of human life on one hand while on other hand; it pollutes the air and water. It has shown hazardous effect of the landscape as well as traditional socialeconomic and socio-cultural values.

Government of India has made obligatory for large mining projects to draw up elaborate plans for protection of environment and for prevention and control of pollution. Such requirement is not insisted in case of small mines in general. The impact of small scale mining operation in cluster form and particularly if the mines happen to be in a hilly region show significant effect on environment. In India, the industrial policy resolution of 1956 did not put any bar on the operation of small mines by small privately owned enterprises.

Air and water are essential for survival of man. So, clean air and potable water should be the primary concern. Broadly environment can be divided into 6 components (1) land (2) water (3) air (4) biota (5) human settlement (6) human body. Mining and other activities related to natural resources may have impact on any of these components either directly or indirectly. The impact of mining on land can be observed through (1) land surface (2) landscape (3) soil fertility (4) land use pattern.

Both the agricultural and forest land has faced hazardous effect of mining activities. In case of open case mining, land surface is completely disturbed whereas underground mining has limited losses. Open cast mining may result in disruption of existing drainage patterns. Similarly, soil fertility is also destroyed in tow ways. Firstly, fertile topsoil is removed during excavation and secondly overburdens along with mine rejects are dumped on the fertile soil cover of landmass around the quarries. Also, excavated material from quarries mixes up with the soil of the land area and damages fertility of the soil. Land use pattern is also disturbed due to cut of forests and shifting of agricultural activities in mine areas.

\section{Degradation Process of Environment}

Apart from quality of surface and groundwater, hydrological system is disturbed by mining activities which ultimately reduce quantity of available water and disturbs aquatic life in the mine areas. The effluents generated by mining and other related activities are discharged into near by areas which ultimately pollutes the water resources. Waste water also work as major pollutant of groundwater. The leachate history is described below: 


\section{Leachate}

Sources:

- Rainfall infiltration

- Groundwater intrusion

- Dissolution of soluble inorganic (e.g. metals)

- Microbial degradation of organics (e.g. paper, cardboard, foodstuffs) to soluble products

Main Components:

- $\quad$ Major ions (Ca, $\mathrm{Mg}, \mathrm{K}, \mathrm{Fe}, \mathrm{Na}$, ammonium, bicarbonate, sulphate, chloride);

- Trace metals (Mn, $\mathrm{Zn}, \mathrm{Cu}, \mathrm{Cr}, \mathrm{Ni}, \mathrm{Pb}, \mathrm{Cd})$;

- Organic compounds (measured as TOC, BOD or COD; may include pesticides, benzenes, phenol);

- Microbiological components.

Leachate chemistry affected by :

- Rate of water infiltration/intrusion and water balance of site;

- Nature of the waste (domestic wastes generally produce leachates with highest pollution potential; industrial/commercial wastes more variable);

- Rate and nature of waste degradation;

- Method of operation of the site;

- Measures taken for leachate management.

- Acetogenic and methanogenic leachates.

- Pollution potential 10-100 times that of raw sewage.

\section{Pollution}

The Bureau of Indian Standard (1996) has defined air pollution as the presence of substances resulting from the activity of man in sufficient concentration and for sufficient time, which render ambient atmosphere to become polluted air. The two components of air pollution are particulate matter and gaseous material. All the human activities viz. house cleaning, earthmoving operations, handling and processing of ore, mining, burning of coal, combustion of engine etc. generate particulate matter whereas gaseous pollutants $-\mathrm{CO}_{2}$ generated from fuel combustions, $\mathrm{CO}$ generated from automobiles, hydrocarbons generated from oil refineries, methane from decomposition of organic matter, $\mathrm{SO}_{2}$ generated through burning of pyrites and oxides of nitrogen like $\mathrm{NO}, \mathrm{NO}_{2}$ etc. from smelters. Polluted air causes damage to tombstones and historical buildings apart from ill effects on the health of organic world. Suspended particles decay metallic structures and substances through corrosion.

Mining and industrial activity adversely affect rate of proliferation of wild life population by associated deforestation, air and water pollution. Over industrialization in some parts of the world has become matter of great concern and environment conscious governments have begun to assess what the societies are losing as a result of industrialization. Local population undergoes both quantitative and qualitative changes due to industrial activities which has brought changes in socio-economic and socio-cultural value systems and even damage to civil structures can be seen e.g. some of the town in Jharia coil field have become unsafe for human habitation due to prolonged extensive mining.

Asbestos has been associated with the disease asbestosis and higher cancer rate as witnessed in Quebea in Canada. Excessive fluorine cause fluorosis and excess selenium causes loss of muscular control, motor ataxia, damage to alimentary canal and disease of the blood forming organs whereas coal dust affects the respiratory system. Excess chromium is related to diseases like diabetes, bronchitis and emphysema.

\section{Environmental Degradation in Rajasthan}

The State of Rajasthan lies between N-latitude $23^{0} 31^{\prime}$ to $30^{\circ} 12^{\prime}$ and longitude E $69^{0} 3^{\prime}$ to $78^{\circ}$ covering an area of 342239 sq.kms. which is $10.74 \%$ of union and largest area in India. The State suffers from vagaries of monsoon having lowest rainfall in western part namely, Jaisalmer district, where it rains around $171 \mathrm{~mm}$ and this rain is not sufficient even to recharge aquifers there and entire rains are consumed as soil moisture, evapotranspiration and allow little or no surface runoff as a result of which even defined channel of stream flows are lacking. However, the story is entirely different in the eastern part of the state and as we move from Jaisalmer-Jodhpur-Ajmer-Jaipur-Dholpur, there is a continuous rise in a rainfall which is around $386 \mathrm{~mm}$ at Jodhpur, $514 \mathrm{~mm}$ at Ajmer, $603 \mathrm{~mm}$ at Jaipur and $819 \mathrm{~mm}$ at Dholpur indicating a climate condition of pure desert to semi desert type.

The State which suffers from such an extreme climate condition in temperature and rainfall also suffers from lack of fresh water in its aquifers and in many western districts there-fourth of the area are only occupied by saline water tract. There was no scientific organization in the State to prospect and delineate the ground water 
potential zones in the State and people were digging their-wells and tube wells on the advice of unscientific method of quacks. The State Government realized the shortcomings and a survey and research wing were opened to prospect for ground water and delineate the fresh potential zones of aquifers in the year 1966.

The present status of ground water condition is quite dismal as per ground water department data water level is going down by 1 to 2 meters every year and till date $3 / 4^{\text {th }}$ of the potential aquifers have been dewatered at the present rate of the ground water withdrawal and if this trend is not arrested timely, may bring havoc in the state even on the brink of rioting amongst the people for water. In near future even tube wells for drinking water will be difficult to be drilled because of the following reasons:

A. Most of the potential zones are on the verge of drying up because of over exploitation.

B. Water level in dug wells and tube wells have declined to a depth, which have become uneconomic as the cost of lift become exorbitantly high.

C. Deterioration of ground water quality with excessive withdrawal of water from the aquifer.

The Rajasthan State can be divided in to four units geomorphologically (1) Aravali hill ranges and adjoining areas, (2) Eastern plain areas, (3) Low lying Vindhayan hill ranges and Deccan lava plateau, (4) Western sandy plains and sand dunes. In each of above areas ground water regime behaves differently. Industrialization and urban development has posed problems of groundwater pollution and environmental hazards. Ground water quality vulnerable areas can be grouped broadly.

(1) Marble Mining and polishing plants: Makarana, Rajsmand, Andhi, Suket, Jhiri and Kishangarh etc.

(2) Base metal mining and processing plants: Khetri, Zawar, Agucha, Rajpura and Bichri etc.

(3) Thermal power generation centers: Kota \& Suratgarh.

(4) Industrial centres : Bhilwara, Udaipur, Sanganer, (Jaipur)

(5) Rapid urbanisation centres : Jaipur, Jodhpur, Udaipur, Kota etc.

The results of study conducted by Baweja and Karanth (1980) for trace element concentration in Khetri area is shown in Table No.1 and Table 2 shows the results of nitrate content in different part of Rajasthan. The results of analysis of trace metals in drinking water and wastewater near Jaipur city are shown in Table No. 3 \& 4 respectively.

Table 1

Trace Element Concentrations in Khetri Copper Project Area

\begin{tabular}{|c|c|c|c|c|}
\hline \multirow{3}{*}{ Constituent } & \multicolumn{3}{|c|}{ Concentration in $\mathrm{mg} / \mathrm{l}$} & \multirow{3}{*}{$\begin{array}{l}\text { Recommended or limit } \\
\text { for drinking }\end{array}$} \\
\hline & \multirow{2}{*}{ Tailings Well No. Pond } & \multicolumn{2}{|c|}{ Well No.44H/16-44H/16- permissible } & \\
\hline & & $3 \mathrm{~A} 15$ & $3 \mathrm{~A} 17$ & \\
\hline $\mathrm{Cu}$ & 0.032 & 0.02 & 0.018 & 1.0 \\
\hline $\mathrm{Pb}$ & 0.40 & 0.08 & 0.085 & 0.05 \\
\hline $\mathrm{Zn}$ & 0.013 & 0.05 & 0.150 & 5.0 \\
\hline $\mathrm{Co}$ & 0.042 & 0.084 & 0.094 & \\
\hline Mo & 0.03 & 0.04 & 0.065 & \\
\hline $\mathrm{Ag}$ & 0.0075 & 0.01 & 0.0155 & 0.015 \\
\hline $\mathrm{Cd}$ & 0.008 & NIL & 0.005 & 0.01 \\
\hline $\mathrm{Li}$ & 0.014 & 0.008 & 0.02 & \\
\hline $\mathrm{Sr}$ & 0.38 & 1.9 & 3.8 & \\
\hline $\mathrm{Rb}$ & 0.0035 & NIL & NIL & \\
\hline
\end{tabular}

Table 2

Nitrate Content in Well Waters in some blocks in Rajasthan

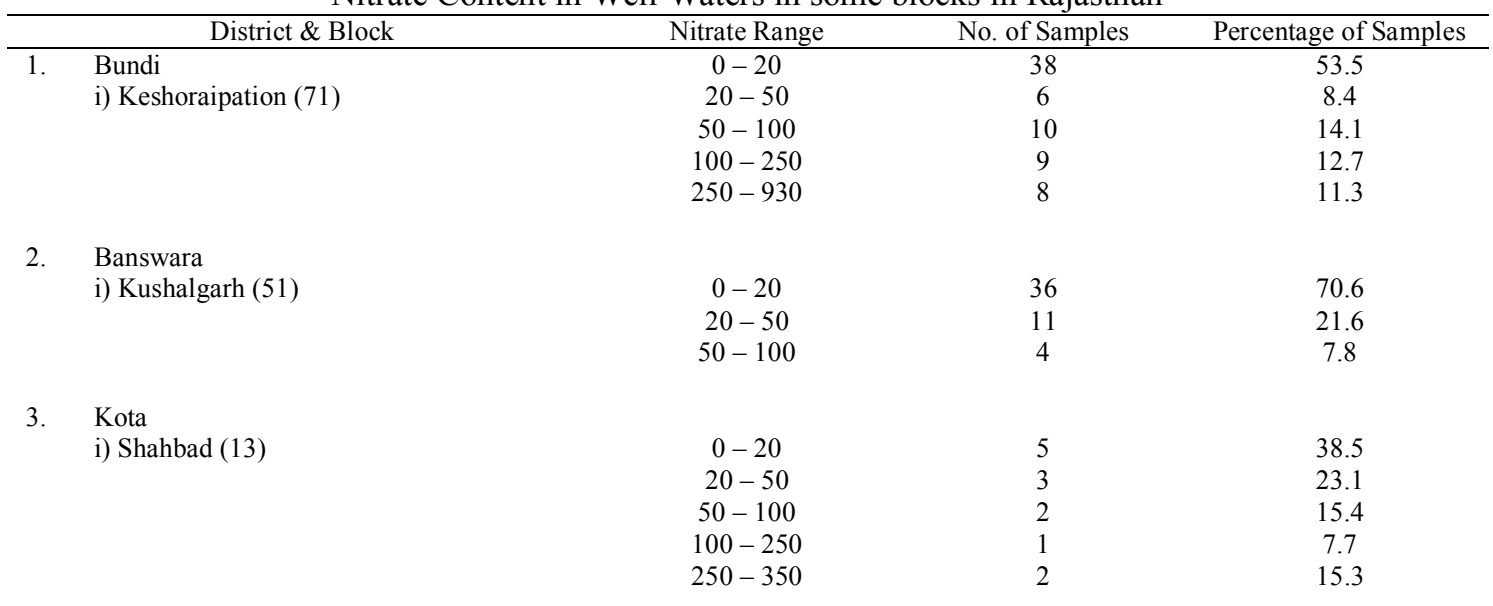


4. Jaipur

i) Chaksu (100)

ii) Dausa (77)
$0-20$

$20-50$

$50-100$

$100-250$

$250-829$

$$
\begin{gathered}
0-20 \\
20-50 \\
50-100 \\
100-250 \\
250-455
\end{gathered}
$$

5. Chittorgarh

i) Chittorgarh (53)

$$
\begin{gathered}
0-20 \\
20-50 \\
50-100
\end{gathered}
$$

\begin{tabular}{lc}
33 & 33 \\
26 & 26 \\
19 & 19 \\
12 & 12 \\
10 & 10 \\
& \\
42 & 54.5 \\
14 & 18.2 \\
9 & 11.7 \\
6 & 7.8 \\
6 & 7.8 \\
& \\
25 & \\
19 & 47.1 \\
7 & 35.9 \\
& 13.2 \\
$\mathbf{1 . 8}$ & \\
\hline
\end{tabular}

100-119

Table 3

Results of Analysis of Trace Metals in Drinking Water, in ppm

(After Karanth)

\begin{tabular}{|l|c|c|c|c|c|c|c|}
\hline \multicolumn{1}{|c|}{ Site } & Zinc & Copper & Manganese & Iron & Lead & Nickel & Cobalt \\
\hline Jawahar Nagar & 22 & 8 & $<5$ & $<5$ & $<5$ & $<5$ & $<5$ \\
\hline Malviya Nagar & 48 & 10 & $<5$ & $<5$ & $<5$ & $<5$ & $<5$ \\
\hline Sanganer & 32 & 6 & $<5$ & $<5$ & $<5$ & $<5$ & $<5$ \\
\hline Vishvakarma & 72 & 20 & $<5$ & $<5$ & $<5$ & $<5$ & $<5$ \\
\hline
\end{tabular}

Note : Arsenic \& cadmium at all sites are NIL

Table 4

Results of Analysis of Trace Metals in Wastewater, in ppm

(After Karanth)

\begin{tabular}{|l|c|c|c|c|c|c|c|}
\hline \multicolumn{1}{|c|}{ Site } & Zinc & Copper & Manganese & Iron & Lead & Nickel & Cobalt \\
\hline Jawahar Nagar & 92 & 180 & $<5$ & $<5$ & $<5$ & $<5$ & $<5$ \\
\hline Malviya Nagar & 105 & 38 & $<5$ & $<5$ & $<5$ & $<5$ & $<5$ \\
\hline Sanganer & 410 & 35 & $<5$ & $<5$ & $<5$ & $<5$ & $<5$ \\
\hline Vishvakarma & 480 & 55 & $<5$ & $<5$ & $<5$ & $<5<$ & $<5$ \\
\hline
\end{tabular}

Note : Arsenic \& cadmium at all sites are NIL

\section{Remedial Measures}

For making pollution free environment, it is necessary to adopt some minimum remedial steps in mining and industrial areas as summarized below:

1. Environmental impact assessment be made obligatory.

2. Monitoring the impact continuously.

3. Complete prevention of environmental hazards where possible.

4. Steps to be taken for restoration of environmental disequilibrium where necessary.

5. Environmental training and education programme should be conducted for mass awakening.

\section{Steps for Mining Sector}

Open cast areas can be restored by back-filling the quarries with waste material or quarries may be converted to lakes, fisheries etc. which would be eco-friendly. Before starting mining operation, top soil should be removed and preserved and later on it should be restored in the original profile. Effective stowing is necessary to prevent subsidence of land overlying underground mines. Waste material generated during mining operation should be piled up in non-pullulated and non-productive law lying land areas which should be situated far away from ephemeral drainage pattern. Toxic waste material should be handled scientifically and treated chemically properly to avoid ill effects on environmental fabric.

Both surface and ground water are liable to pollution. Pollution in ground water make water unsafe for human use and it can not be detected readily and remedied in comparison to surface water pollution. Ground water pollution is easily located at industrial centers where untreated wastes are disposed. Nitrate pollution is widespread in rural areas caused by excessive use of pesticides and urea for enhancing agricultural products. The lack of proper drainage system and unplanned sewage disposal in city areas easily make ground water polluted. Artificial fluoride pollution is mainly caused by super phosphate fertilizer plants. Ground water pollution may remain undectable due to removal of many elements of pollution viz. colour, odour, turbidity etc. 
by the soil, subsoil and aquifer material through which polluting gents are filtered during downward percolation of water. According to Hem (1970) although some polluted surface water can be restored to reasonable quality levels fairly rapidly, pollution of ground water may be so slow to recover from the polluted condition that is become necessary to think of the pollution of aquifers as almost irreversible once it has occurred, for which reason great care is needed to protect ground water supplies.

\section{Steps for Water Preservation and Conservation}

With the increasing population and industrialization, there is growing dependability on ground water, which ultimately makes this natural resource precious. To avoid pollution of groundwater it requires being conserved and protected. Primary, water conservation can be achieved through the following measures.

(1) Recycling of industrial wastewater after essential treatment be made mandatory.

(2) Proper treatment of industrial and mining waste material be made mandatory before disposal of the same.

(3) Closed water circuit for the mineral handling and processing plants should be designed for maintenance of quantity of water leaving from plants at the minimum level.

(4) Development and improved maintenance of sewerage disposal system so as to minimize nitrate pollution.

(5) Creation of Reservoirs: Surplus water flowing down to sea unutilized could be prevented by creation of reservoirs and water stored in them can be utilized for irrigation, hydropower and water supply etc.

(6) Research is needed for control of evaporation of water from surface bodies.

(7) Water pricing: Incentive for economical use of water by farmers needs to be introduced.

(8) Reduction in demand of water: It could be achieved by selection of cropping pattern based on its efficiency in utilization of water.

(9) Improvement on water use efficiency: It could be achieved by the followings:

(a) By adoption of sprinkler and drip irrigation.

(b) By adoption of conjunctive use of surface and ground water which reduces water logging, salinity and alkalinity of soil.

(c) By lining of canals and distributaries.

10. People's participation: By organizing education and awareness programmes at grass root level. Since most of the farmers of the country are illiterate, training to them becomes necessary so that habit for economical use of water could be developed in the farmers. NGO cooperative and voluntary agencies can be assigned the work of maintenance of public water supply tube wells and pumps.

11. Interbasin transfer: Equitable distribution and optimum utilization of water can also be achieved by transfer of water from surplus water possessing river basin to water deficit river basins so that waste water flowing to sea could be used properly.

12. Rain water harvesting: Artificial recharge of ground water through roof-top rain water harvesting in public and individual household in all municipal areas should be made mandatory.

\section{Conclusion}

Looking to the present condition existing in the state and results available of various studies points a very poor position of availability of water, unless massive effort is made for utilizing every drop of rain water by diverting excess water to artificial recharging purpose so as to arrest the declining trend of water level. There is a need to bring ground water legislation to regularize the use of ground water in the State. There is also need to accurately assess the recharge to ground water as the present methodology followed by State Ground Water Department is on adhoc norms and it should be replaced by use of isotope hydrology methods which takes 3 to 7 years to assess the actual recharge to ground water.

\section{References}

[1]. Das Gupts 1991 : Study on Ground Water Quality and Monitoring in Asia and the Pacific, Water Resources Series No.70.

[2]. Baweja, B.K. \& Karnath, K.R. 1980 : Ground Water Pollution Studies in India, Bull. No.5, Tech. Series H, C.G.W.B.

[3]. Bouwer, H. 1978 : Ground Water Hydrology, McGraw Hill, New York.

[4]. Davis D.N. and Dewiest, R.J.M. 1968 : Hydrogeology John Willey \& Sons, New York.

[5]. Foster, M.D. 1942 : Chemistry of Ground Water in Hydrology McGraw Hill, New York.

[6]. Garg, S.P. 1984 : Ground Water and Tube Wells Oxford \& IBH Publishing Co. $2^{\text {nd }}$ Edn., New Delhi.

[7]. Ground Water Basin Management "ASCE Manual of Engineering Practice No.40", American Society of Civil Engineer, New York, 1967.

[8]. Heath R.C. and Frenk W. Trainer 1968 : Introduction of Ground Water Hydrology, John Willey \& Sons, New York.

[9]. Hem, J.C. 1970 : Study and Interpretation of the Chemical Characteristics of Natural Water U.S.G.S. Water Supply Paper, 1473.

[10]. Indian Standard Institute (ISI) 1968 : Indian Standard Specification for Drinking Water.

[11]. Jacob, C.E. 1960 : Flow of Ground Water in Engineering Hydraulics, John Willey \& Sons, New York. 
[12]. Karanth, K.R. 1987 : Groundwater Assessment Development and Management, Tata McGraw-Hill Publishing Company Ltd., New Delhi.

[13]. Maanju, S.K. 1992 : Hydrogeology and Hydrochemistry of Part of Moral Basin, Jaipur District, Rajasthan, India. Unpublished Ph.D Thesis, University of Rajasthan, Jaipur.

[14]. Rima, D.R. Chase, E.B. and Mayers, B.M., 1971 : "Sub-surface Disposal by Means of Wills - A Selected Annotated Bibliography", U.S. Geological Society Paper 2020.

[15]. Singor, D.C. Growetz, D.J. and Kam, W. 1971 : Annotated Bibliography on Artificial recharge of Ground Water 1955-67, U.S. Geological Survey Water Supply Paper 1990.

[16]. Todd, D.K., 1959 : Ground Water Hydrology, John Wiley \& Sons, New York. 